\title{
Examination of PHB Depolymerases in Ralstonia eutropha: Further Elucidation of the Roles of Enzymes in PHB Homeostasis
}

\author{
Christopher J Brigham', Esther N Reimer ${ }^{2}$, ChoKyun Rha ${ }^{3}$ and Anthony J Sinskey ${ }^{1,4,5^{*}}$
}

\begin{abstract}
Polyhydroxyalkanoates (PHA) are biodegradable polymers that are attractive materials for use in tissue engineering and medical device manufacturing. Ralstonia eutropha is regarded as the model organism for PHA biosynthesis. We examined the effects of PHA depolymerase (PhaZ) expression on PHA homeostasis in $R$. eutropha strains. In order to analyze the impact of PhaZs on R. eutropha granule architecture, we performed electron microscopy on several phaZ knockout strains and the wild type strain grown under PHA production conditions. Analysis of the acquired micrographs was based on stereology: the ratio of granule area and cell area was determined, along with total granule count per full-size cell image. Cells bearing a phaz2 knockout mutation alone or in conjunction with a phaZ1 mutation were found to have a high granule volume per cell volume and a higher granule count compared to wild type. A phaZ quadruple knockout strain appeared to have a low granule volume per cell volume and a low granule count per cell. Cells bearing a phaz3 knockout were found to have a higher granule count than the wild type, whereas granule volume per cell volume was similar. Accordingly, we hypothesize that PhaZs have not only an impact on PHA degradation but also on the 3-dimensional granule architecture. Based on our data, PhaZ2 is postulated to affect granule density. This work increased our knowledge about PHA depolymerases in R. eutropha, including enzymes that had previously been uncharacterized.
\end{abstract}

Keywords: Ralstonia eutropha, Polyhydroxyalkanoates, Polyhydroxybutyrate, Biomaterials, Depolymerase, Granules, Carbon utilization, Electron microscopy, Stereology

\section{Introduction}

Polyhydroxyalkanoates (PHA) are carbon storage molecules synthesized by many microorganisms during times of (non-carbon) nutrient stress. One of the most well-studied members of the PHA family is the homopolymer polyhydroxybutyrate (PHB). Several species of bacteria have been shown to produce PHB (see (Anderson and Dawes 1990; Rehm 2003; Stubbe et al. 2005; Sudesh et al. 2000) for reviews), including Ralstonia eutropha, which is considered the model organism for study of PHA biosynthesis (Reinecke and Steinbüchel 2009). R. eutropha grows autotrophically (Ishizaki et al. 2001; Volova and Voinov 2003) or heterotrophically on carbon substrates such as fructose

\footnotetext{
* Correspondence: asinskey@mit.edu

1 Department of Biology, Massachusetts Institute of Technology, Cambridge, MA 02139, USA

${ }^{4}$ Division of Health Sciences Technology, Massachusetts Institute of Technology, Cambridge, MA 02139, USA
}

Full list of author information is available at the end of the article
(Tian et al. 2005b), organic acids (Yang et al. 2010), or fatty acids/lipids (Brigham et al. 2010) and has been demonstrated to produce PHB under nitrogen or phosphate limitation. PHA, including but not limited to PHB, have been shown to exhibit a range of thermal and physical properties similar to petroleum-based plastics (Budde et al. 2011; Sudesh et al. 2000), and have also been shown to be biodegradable (Shishatskaya et al. 2005).

Both the ubiquity of PHB, and various PHA types, and the production of low molecular weight PHB in a range of organisms, including mammals (Reusch 1989), have led researchers to extensive examination of PHAs for use in medical materials and devices. PHAs have been demonstrated to be biocompatible and have been used in surgical procedures (Shishatskaya et al. 2002a; Shishatskaya et al. 2002b; Shishatskaya et al. 2004; Sodian et al. 1999). The immunological and histological responses of tissues and organisms towards PHA implants have demonstrated 
favorable results (Sevastianov et al. 2003; Shishatskaya et al. 2004; Volova et al. 2003). PHA is currently being used to produce commercially available sutures and meshes that have shown to exhibit many promising characteristics, including durability, tensile strength, flexibility, and resorbability (www.tepha.com). PHA matrices are also being examined for encapsulation of bioactive agents, such as tumor drugs and antibiotics, to be inserted and delivered at the site of tissue distress (Chee et al. 2008). Many PHA types have been used as growth substrata for cells in tissue engineering (Chen and $\mathrm{Wu}$ 2005). In earlier studies, a copolymer of polyglycolic acid (PGA) and PHB was used to produce pulmonary valve leaflets and pulmonary artery scaffolds in sheep (Shum-Tim et al. 1999). This study was followed up by construction of a PHA-based heart valve scaffold, which was again surgically inserted into sheep (Sodian et al. 1999). Both of these early studies illustrated that tissue engineering using biopolymer scaffolds is possible. Fibroblast cells from the NIH 3T3 line have been shown to exhibit growth on PHB and PHA copolymer substrates. These polymers have good functional properties in both an in vitro and in vivo setting (Shishatskaya et al. 2008). PHB composites have been constructed, such as PHB with hydroxyapatite for bone tissue engineering (Chen and Wu 2005). PHA, specifically a copolymer of 3hydroxybutyrate and 4-hydroxybutyrate (P(3HB-co-4HB)), shown to be a promising substrate for growing rabbit smooth muscle cells and demonstrated high elastin formation, suggesting efficacy of PHA in tissue engineering (Cheng et al. 2008).

Even with the number of important discoveries that have been made regarding $R$. eutropha PHB metabolism, physiology, and biochemistry over the past few decades, there are still attributes of PHB metabolism and intracellular granule formation that remain to be fully explained. In this work, we examine PHB depolymerase enzymes, termed PhaZ, and their role in $R$. eutropha PHB utilization and intracellular PHB granule formation. Table 1 lists established and putative PHA depolymerases in $R$. eutropha. The principle depolymerase enzyme of $R$. eutropha, PhaZ1, has been well-studied and plays a significant role in PHB mobilization (Uchino and Saito 2006; Uchino et al. 2007; York et al. 2003). Another depolymerase enzyme, PhaZ2, has been shown to degrade PHB intracellularly (York et al. 2003). It is important to note that, in published research prior to publication of the $R$. eutropha H16 genome sequence in 2006, what is now catalogued as PhaZ5 was referred to as PhaZ3. A new and currently uncharacterized PhaZ3 enzyme is now referenced. Two depolymerase candidates, PhaZ3 and PhaZ5, exhibit homology to other intracellular depolymerases and are even classified in the PHA Depolymerase Engineering Database (http://www. ded.uni-stuttgart.de/) as intracellular, short-chain PHA depolymerases that act on native PHA (Knoll et al. 2009). One candidate, PhaZ5 (formerly PhaZ3) has been discussed in previous works (York et al. 2003), while PhaZ3 has not been characterized to date. Here, we describe the PHB mobilization phenotype of a phaZ3 mutant strain, alone or in conjunction with other phaZ gene deletions. We also examine expression of $p h a Z$ genes and determine if absence or overexpression of specific phaZ genes influences PHB homeostasis. Lastly, we examine phaZ mutant strains by electron microscopy and suggest PHB remodeling for PhaZ enzymes associated with PHB granules.

\section{Materials and methods}

\section{Bacterial strains, plasmids and primers}

The bacterial strains used in this work are listed in Table 2. Oligonucleotide primers used in this study are listed in Table 2. All plasmids for overexpression of phaZ genes

Table $1 R$. eutropha PHA depolymerase and related enzymes

\begin{tabular}{|c|c|c|c|c|}
\hline Name & Function & PHA Depolymerase Superfamily designation ${ }^{a}$ & Protein ID ${ }^{\mathbf{b}}$ & Locus tag \\
\hline PhaZ1 & Intracellular PHA depolymerase & i-nPHAscl (no lipase box) & CAJ92291.1 & H16_A1150 \\
\hline PhaZ2 & Intracellular PHA depolymerase & i-nPHAscl (no lipase box) & CAJ93939.1 & H16_A2862 \\
\hline PhaZ3 & Putative intracellular PHA depolymerase & i-nPHAscl (no lipase box) & CAJ95139.1 & H16_B0339 \\
\hline PhaZ4 & Putative PHA depolymerase & i-nPHAscl (no lipase box) & AAP85930.1 & PHG178 \\
\hline PhaZ5 & Intracellular PHA depolymerase & i-nPHAscl (no lipase box) & CAJ95805.1 & H16_B1014 \\
\hline PhaZ6 & PHA depolymerase & e-dPHAscl (catalytic domain type 1) & CAJ96855.1 & H16_B2073 \\
\hline PhaZ7 & PHA depolymerase & e-dPHAscl (catalytic domain type 1) & CAJ97183.1 & H16_B2401 \\
\hline PhaY1 & D-(-)-3-hydroxybutyrate oligomer hydrolase & $N / A^{d}$ & CAJ93348.1 & H16_A2251 \\
\hline PhaY2 & D-(-)-3-hydroxybutyrate oligomer hydrolase & $N / A^{d}$ & CAJ92475.1 & H16_A1335 \\
\hline
\end{tabular}

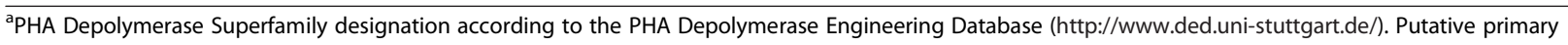
protein sequences of each PHA depolymerase were used as seed sequences for a BLAST search of enzymes present in the database. Each depolymerase candidate is also classified according to a superfamily, as discussed in (Knoll et al. 2009).

${ }^{\mathrm{b}}$ From DNA Data Bank of Japan (http://www.ddbj.nig.ac.jp/).

'Originally characterized as PhaZd (Abe et al. 2005).

${ }^{\mathrm{d}}$ Sequence characteristics not present in PHA Depolymerase Engineering Database. 
Table 2 Bacterial strains and plasmids used in this study

\begin{tabular}{|c|c|c|}
\hline $\begin{array}{l}\text { Strain or } \\
\text { Plasmid }\end{array}$ & Description & Reference \\
\hline \multicolumn{3}{|c|}{ R. eutropha strains } \\
\hline $\mathrm{H} 16$ & Wild type, Gm resistant & ATCC 17699 \\
\hline $\operatorname{Re} 1097$ & H16/DphaZ1 & (York et al. 2003) \\
\hline $\operatorname{Re} 1107$ & H16/DphaZ5 & (York et al. 2003) \\
\hline $\operatorname{Re} 1110$ & $\mathrm{H} 16 / \Delta p h a Z 2$ & (York et al. 2003) \\
\hline $\operatorname{Re} 1111$ & 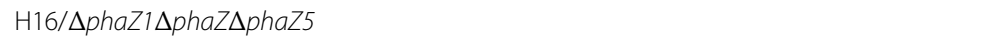 & (York et al. 2003) \\
\hline $\operatorname{Re} 1112$ & $\mathrm{H} 16 / \Delta p h a Z 1 \Delta p h a Z 2$ & (York et al. 2003) \\
\hline $\operatorname{Re} 2005$ & 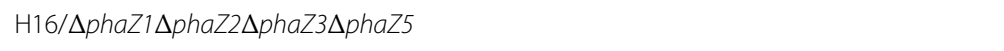 & This study \\
\hline $\operatorname{Re} 2006$ & H16/DphaZ3 & This study \\
\hline \multicolumn{3}{|l|}{ E. coli strains } \\
\hline Top10 & $\begin{array}{l}\text { IF }^{-} \text {mcrA } \Delta \text { (mrr-hsdRMS-mcrBC) } \varphi 80 \text { lacZDM15 } \Delta \text { lacX74 recA1 araD139 } \Delta \text { (ara-leu) } 7697 \\
\left.\text { galU galK rpsL (Str }{ }^{R}\right) \text { endA1 nupG } \lambda \text { - }\end{array}$ & Invitrogen \\
\hline S17-1 & recA pro hsdR RP4-2-Tc::Mu-Km::Tn7 & ATCC47055; (Simon et al. 1983) \\
\hline \multicolumn{3}{|l|}{ Plasmids } \\
\hline pBBR1MCS-2 & Broad host range cloning vector, confers $\mathrm{Km}$ resistance & (Kovach et al. 1995) \\
\hline pER1 & pBBR1MCS-2 with phaZ1 inserted into $\mathrm{Kpn} 1 / \mathrm{Xba} 1$ restriction sites, confers $\mathrm{Km}$ resistance & This study \\
\hline pER2 & pBBR1MCS-2 with phaZ2 inserted into Kpn1/Xba1 restriction sites, confers Km resistance & This study \\
\hline pER3 & pBBR1MCS-2 with phaZ3 inserted into Sal1/Xba1 restriction sites, confers Km resistance & This study \\
\hline pER4 & pBBR1MCS-2 with phaZ5 inserted into Kpn1/Xba1 restriction sites, confers Km resistance & This study \\
\hline pGY46 & phaC precise-deletion gene replacement plasmid, confers $\mathrm{Km}$ resistance & (York et al. 2001) \\
\hline pCJB3 & pGY46 with regions upstream and downstram of phaZ3 inserted between Sacl and Xbal & This study \\
\hline
\end{tabular}

were derived from the broad host range vector pBBR1MCS-2 (Table 2). The Escherichia coli strain TOP10 was used for the amplification of the plasmids throughout the cloning process, and E.coli strain S17-1 was used for conjugal transfer of plasmids into $R$. eutropha $\mathrm{H} 16$.

\section{Materials}

All chemicals were TT86d47313purchased from SigmaAldrich, (St. Louis, MO, USA) unless indicated differently below. The following kits were used according to the instructions given by the manufacturer: The QIAquick ${ }^{\circledR}$ Gel Purification Kit (Qiagen, Valencia, CA) for gel purification of DNA and the QIAprep ${ }^{\oplus}$ Spin Miniprep Kit (Qiagen, Valencia, CA) for the isolation of plasmids. PCR was performed using the Phusion ${ }^{\odot}$ PCR Master Mix (Finnzymes, Lafayette, $\mathrm{CO}$ ) according to instructions provided by the manufacturer. All DNA modification enzymes used in this study were obtained from New England Biolabs (Ipswich, MA, USA) unless indicated differently.

\section{Culture media formulation}

Bacto $^{\mathrm{Tm}}$ Tryptic Soy Broth without Dextrose (TSB, Becton Dickinson, Sparks, MD) was used as a rich culture medium for $R$. eutropha strains. For the growth of all $R$. eutropha strains, $10 \mu \mathrm{g} / \mathrm{mL}$ gentamycin sulfate (Gm10) was added. For the growth of $R$. eutropha strains containing a plasmid conferring a kanamycin resistance, $300 \mu \mathrm{g} / \mathrm{mL}$ kanamycin sulfate (Kan300, Calbiochem, USA) was added to the media. Minimal medium for $R$. eutropha was composed of $4.0 \mathrm{~g} / \mathrm{L} \mathrm{NaH} \mathrm{NPO}_{4}, 0.45 \mathrm{~g} / \mathrm{L}$ $\mathrm{K}_{2} \mathrm{SO}_{4}, 0.39 \mathrm{~g} / \mathrm{L} \mathrm{MgSO}_{4}, 62 \mathrm{mg} / \mathrm{L} \mathrm{CaCl}_{2}$ and $1 \mathrm{~mL}$ per $1 \mathrm{~L}$ of a trace element solution $\left(15 \mathrm{~g} / \mathrm{L} \mathrm{FeSO}_{4} \cdot 7 \mathrm{H}_{2} \mathrm{O}\right.$, $2.4 \mathrm{~g} / \mathrm{L} \mathrm{MnSO}_{4} \cdot \mathrm{H}_{2} \mathrm{O}, 2.4 \mathrm{~g} / \mathrm{L} \mathrm{ZnSO}_{4} \cdot 7 \mathrm{H}_{2} \mathrm{O}$ and $0.48 \mathrm{~g} / \mathrm{L} \mathrm{CuSO}_{4} \cdot 5 \mathrm{H}_{2} \mathrm{O}$ dissolved in $\left.0.1 \mathrm{M} \mathrm{HCl}\right)$. The initial $\mathrm{pH}$ of the minimal medium was 6.8. Nitrogen and carbon sources were added to minimal medium as indicated below. All $R$. eutropha strains and cultures were grown at a temperature of $30^{\circ} \mathrm{C}$.

Lysogeny broth (LB) was used as culture medium for E. coli and in the mating and selection process of $R$. eutropha mutants. LB containing $50 \mu \mathrm{g} / \mathrm{mL}$ kanamycin (Kan50) was used for $E$. coli harboring plasmids. All $E$. coli cultures were grown at a temperature of $37^{\circ} \mathrm{C}$.

\section{Creation of $R$. eutropha strains}

For the creation of the plasmids pER1, pER2, pER3 and pER4 (see Table 2), phaZ genes were inserted into the plasmid pBBR1MCS-2, as discussed below. The genes phaZ1, phaZ2, phaZ3 and phaZ5 (Handrick et al. 2000; York et al. 2003) were amplified from $R$. eutropha H16 via 
PCR, using primers listed in Table 3. A double restriction digest was performed on both the plasmid pBBR1MCS-2 (see Table 2) and the inserts, using Kpn1 and Xba1 for the formation of pER1, pER2, pER4, or Sal1 and Xba1 for the formation of pER3. To construct a phaZ3 deletion allele, two sets of primers were used to amplify two $\sim 500 \mathrm{bp}$ regions of DNA, directly flanking the phaZ3 open reading frame. Primers phaZ3del1 and phaZ3del2 (Table 3) were used to amplify a fragment directly upstream of the phaZ3 open reading frame. Primers phaZ3del3 and phaZ3del4 (Table 3) were used to amplify a fragment directly downstream of the phaZ3 gene. The upstream insert was then digested with Sac1 and Pst1 and the downstream insert was digested with Pst1 and Xba1. The plasmid pGY46 (see Table 2) was digested with Sac1 and Xba1 to remove the phaC deletion allele. The purified digests of plasmid and desired inserts were ligated overnight at $15^{\circ} \mathrm{C}$ using $\mathrm{T} 4$ DNA ligase, following the manufacturer's instructions. Conjugal transfer of plasmids into $R$. eutropha was performed by a standard procedure described previously

Table 3 Primers used in this study

\begin{tabular}{|c|c|}
\hline Name/purpose & Sequence $\left(5^{\prime}-3^{\prime}\right)^{*}$ \\
\hline \multicolumn{2}{|c|}{ Deletion of phaZ3 gene } \\
\hline phaZ3del1 & CAT AGA GCT CAT CGC TGC GGC AAC TTG GG \\
\hline phaZ3del2 & GAC ACT GCA GCA TGA AGA CTC CCG TAG GAA \\
\hline phaZ3del3 & GAT ACT GCA GAC TTA GCA TCG CCT GCC C \\
\hline phaZ3del4 & CAA GTC TAG AGA CGC GTG AAC AAG CTG \\
\hline phaZ3delchkFW & CGG TGA ACC ATC GAA TTC \\
\hline phaZ3delchkRV & CAA GGT TGA CCG CAG CAA G \\
\hline \multicolumn{2}{|c|}{ Plasmid-based overexpression of phaZ genes } \\
\hline PhaZ1 FW & GCA CGG TAC CAT GCT CTA CCA ATT GCA TGA G \\
\hline Pha Z1 RV & GAT ATC TAG ATT ACC TGG TGG CCG AGG CCT G \\
\hline Pha Z2 FW & CAT AGG TAC CAT GCT GTA CCA CGC CTA CCA \\
\hline Pha Z2 RV & GCG TTC TAG ATT AGC TGC TGG TGT AGA TGG \\
\hline Pha Z3 FW & CTA TGT CGA CAT GCT GTA CCA GCT CGT CGA G \\
\hline Pha Z3 RW & CAA GTC TAG ACT AAG TAT CGT GCC CGG TCA \\
\hline Pha Z5 FW & AAT TGG TAC CAT GGC GCT CTA TGC TCT GCG \\
\hline Pha Z5 RW & GAA TTC TAG ATC AGT CGG CGC ACC GTT GAA \\
\hline \multicolumn{2}{|c|}{ RT-PCR to quantify overexpression of phaz genes } \\
\hline PhaZ1 FW & CCATCAAGCTGCTCAAGGAT \\
\hline Pha Z1 RV & CCAGTCGGTGACGTAGACCT \\
\hline Pha Z2 FW & TCTACCTGGAAACCGTCAGC \\
\hline Pha Z2 RV & CAGATATCGTCGCGTTCACC \\
\hline Pha Z3 FW & GGACTATTGCCTGGATCTCG \\
\hline Pha Z3 RV & AATTCCTGGAACACGAGCTG \\
\hline Pha Z5 FW & ATGATCGAGGCAGGTTATCG \\
\hline Pha Z5 RV & GACCTCGTCGATCTCAAAGC \\
\hline
\end{tabular}

*Restriction sites indicated in bold.
(Budde et al. 2010; Quandt and Hynes 1993). For deletion of the phaZ3 gene, $R$. eutropha strains H16 and Re1111 were used as parental strains. To determine the presence of the $\triangle p h a Z 3$ allele in the $R$. eutropha chromosome, diagnostic PCR was performed using the primers phaZ3delchkFW and phaZ3delchkRV (see Additional file1: Figure S1). Strains positive for phaZ3 deletion (Re2005 and Re2006, see Table 2) were used for further study.

\section{RNA Extraction and reverse transcriptase quantitative PCR} For examination of phaZ gene overexpression in $R$. eutropha strains containing plasmid, total RNA extraction and reverse transcriptase quantitative PCR (RT-qPCR) were performed. $R$. eutropha strains containing plasmids were propagated in a $5 \mathrm{~mL}$ liquid culture of TSB/Kan300+ $\mathrm{Gm} 10$ at $30^{\circ} \mathrm{C}$ for approximately $40 \mathrm{~h}$, and then used to inoculate a $50 \mathrm{~mL}$ culture of TSB/Kan300+ Gm10 to an $\mathrm{OD}_{600}$ of 0.1 . The $50 \mathrm{~mL}$ cultures were incubated in a $500 \mathrm{~mL}$ shaking flask at $30^{\circ} \mathrm{C}$ and $200 \mathrm{rpm}$ for $\sim 8 \mathrm{~h}$. The $\mathrm{OD}_{600}$ was measured and $2.5 \mathrm{OD}$ units were transferred into a conical tube (BD Flacon). The cells were centrifuged at $5000 \mathrm{rpm}$ and the supernatant was removed. The pellet was dried and quickly frozen by incubating in a slurry of dry ice and ethanol. Pellets were stored at $-80^{\circ} \mathrm{C}$ until used for RNA extraction.

Total cellular RNA was extracted from R. eutropha strains using a method described previously (Brigham et al. 2010). Determination of RNA concentration and purity were performed on a Nanodrop 1000 (Thermo Scientific, Wilmington, DE) directly before using the purified RNA for RTqPCR. RT-qPCR analysis was performed using the QuantiTect Reverse Transcription Kit (Qiagen, Valencia, CA) according to the manufacturer's instructions. For each reaction, 100 ng of total cellular RNA was used. A reaction mixture without reverse transcriptase was used as a control for each sample. Product quantification was performed using the QuantiTect SYBR Green PCR Kit (Qiagen, Valencia, $\mathrm{CA}$ ) according to the manufacturer's instructions. The total reaction volume was $25 \mu \mathrm{L}$. One reaction mix without template cDNA was used as an additional control. For determination of cDNA concentration, the desired primer product was amplified via PCR using genomic DNA from $R$. eutropha. The PCR product was gel purified and serial dilutions were prepared $\left(1: 10,1: 10^{2}, 1: 10^{3}, 1: 10^{4}, 1: 10^{5}\right.$, $\left.1: 10^{6}, 1: 10^{7}, 1: 10^{8}\right)$. RT-qPCR was performed on selected aliquots of these DNA-dilutions in order to create standard curves $\left(1: 10^{2}, 1: 10^{3}, 1: 10^{4}\right.$, and $1: 10^{5}$ for phaZ1 and phaZ2; $1: 10^{2}, 1: 10^{3}, 1: 10^{4}, 1: 10^{5}$, and $1: 10^{6}$ for phaZ3; $1: 10^{4}, 1: 10^{5}$, $1: 10^{6}, 1: 10^{7}$, and $1: 10^{8}$ for phaZ5).

Analysis of PHB production and depletion in $R$. eutropha strains harboring plasmid-borne phaZ genes

The strains H16/pBBR1MCS-2, H16/pER1, H16/pER2, H16/pER3, H16/pER4, Re2005/pBBR1MCS-2, Re2005/ 
pER1, Re2005/pER2, Re2005/pER3 and Re2005/pER4 were initially propagated in $5 \mathrm{~mL}$ of $\mathrm{TSB} / \mathrm{Kan} 300+$ $\mathrm{Gm} 10$ at $30^{\circ} \mathrm{C}$ for approximately $40 \mathrm{~h}$.

For rich medium cultures, a $200 \mathrm{~mL}$ culture of TSB/ $\mathrm{Kan} 300+\mathrm{Gm} 10$ in a $1 \mathrm{~L}$ shaking flask was inoculated to an initial $\mathrm{OD}_{600}$ of 0.05 . It was incubated at $30^{\circ} \mathrm{C}$ and $200 \mathrm{rpm}$ for a total of $72 \mathrm{~h}$. To determine the PHB content a $5 \mathrm{~mL}$ sample was taken immediately after inoculation $(0 \mathrm{~h})$. Following the initial sampling, culture aliquots of $30 \mathrm{~mL}$ were removed at intermittent time points for the same purpose.

For cultures in PHB production medium, cells from rich media precultures were washed once with a sterile $0.85 \%$ $\mathrm{NaCl}$ solution and used to inoculate a $200 \mathrm{~mL}$ culture of minimal medium enriched with $2 \%$ fructose and $0.05 \%$ $\mathrm{NH}_{4} \mathrm{Cl}$ to an initial $\mathrm{OD}_{600}$ of 0.05 in a $1 \mathrm{~L}$ culture flask. Cultures were incubated at $30^{\circ} \mathrm{C}$ with agitation at $200 \mathrm{rpm}$ for a total of $72 \mathrm{~h}$. Following inoculation, $5 \mathrm{~mL}$ of culture were removed to determine PHB content $(0 \mathrm{~h})$. After the first sampling, the following sample volumes were removed and used to determine PHB content of cells in culture: $25 \mathrm{~mL}$ after $4 \mathrm{~h}, 15 \mathrm{~mL}$ after $8 \mathrm{~h}$ and $10 \mathrm{~h}, 10 \mathrm{~mL}$ after 24 , 48 and $72 \mathrm{~h}$.

To formulate PHB consumption medium, $0.1 \% \mathrm{NH}_{4} \mathrm{Cl}$ and no carbon source were added to $R$. eutropha minimal medium (see above). For PHB consumption cultures, after $72 \mathrm{~h}$ growth under conditions for $\mathrm{PHB}$ production, $100 \mathrm{~mL}$ aliquots of culture were removed, washed with a sterile $0.85 \% \mathrm{NaCl}$ solution and transferred into $100 \mathrm{~mL}$ of $\mathrm{PHB}$ consumption medium in $500 \mathrm{~mL}$ culture flasks. These cultures were incubated at $30^{\circ} \mathrm{C}$ and $200 \mathrm{rpm}$ for a total of $72 \mathrm{~h}$. At intermittent time points in the culture, aliquots were removed to determine PHB content of the cells in culture.

The PHB content was assayed indirectly as crotonic acid by the high-pressure liquid chromatography (HPLC) method developed by Karr et al. (Karr et al. 1983) and performed in our laboratory as described previously (Brigham et al. 2010; Budde et al. 2010). Averages $(\bar{x})$ and standard deviation $(\sigma)$ were calculated using the formulas $(1)$ and (2). $\mathrm{n}$ is the number of experiments $(\mathrm{n}=2), x_{i}$ is PHB \% of cell dry weight $(\% \mathrm{CDW})$ at a defined time point.

$$
\begin{aligned}
& \overline{\mathrm{x}}=\frac{\sum \mathrm{x}_{\mathrm{i}}}{\mathrm{n}} \\
& \sigma=\sqrt[2]{\frac{\sum\left(\mathrm{x}_{\mathrm{i}}-\overline{\mathrm{x}}\right)^{2}}{\mathrm{n}-1}}
\end{aligned}
$$

\section{Electron Microscopy}

The following $R$. eutropha strains with deletions of one or more phaZ genes were imaged under a Jeol JEM-1200 EXII electron microscope (JEOL, Tokyo, Japan) at $59 \mathrm{kV}$ :
H16, Re1097, Re1107, Re1110, Re1112, Re2005, and Re2006 (see Table 2). Micrographs were acquired using an AMT V600 Camera (Advanced Microscopy Techniques, Danvers, MA, USA) and the corresponding software. NIS elements software (V 2.03, Nikon Instruments, Melville, NY) was used to analyze the images.

Growth of $R$. eutropha strains was carried out as follows. The strains were propagated in a $5 \mathrm{~mL} \mathrm{TSB} / \mathrm{Gm} 10$ liquid culture at $30^{\circ} \mathrm{C}$ for approximately $40 \mathrm{~h}$. After $40 \mathrm{~h}$, $1 \mathrm{~mL}$ of culture was used to inoculate a $50 \mathrm{~mL}$ liquid culture of TSB/Gm10 in a $250 \mathrm{~mL}$ shaking flask. This flask culture was incubated at $30^{\circ} \mathrm{C}$ with agitation of $200 \mathrm{rpm}$ for $24 \mathrm{~h}$. Cells from this culture were washed and used to inoculate a $25 \mathrm{~mL}$ minimal medium culture containing $2 \%$ fructose and $0.05 \% \mathrm{NH}_{4} \mathrm{Cl}$ to an initial $\mathrm{OD}_{600}$ of 0.5 . The culture was incubated in a $250 \mathrm{~mL}$ shaking flask at $30^{\circ} \mathrm{C}$ with agitation of $200 \mathrm{rpm}$. After approximately $22 \mathrm{~h}, 1.5 \mathrm{~mL}$ of cell culture were harvested from each flask and aliquots from each culture were taken and used for preparation of EM grids.

Embedding procedure of cells and preparation of EM grids was performed as follows. The cells harvested were washed twice with $50 \mathrm{mM}$ HEPES buffer ( $\mathrm{pH} \mathrm{7)}$ and enrobed in $2 \%$ molten Noble Agar. Once the agar had solidified, it was cut into $2 \mathrm{~mm} \times 2 \mathrm{~mm}$ squares using a clean heated razor blade. The blocks were transferred into a microcentrifuge tube, resuspended in $0.5 \mathrm{~mL} 2 \%$ glutaraldehyde and stored for $1-2 \mathrm{~h}$ at room temperature. The blocks were washed three times in HEPES buffer $(50 \mathrm{mM}, \mathrm{pH} 7)$, resuspended in $0.5 \mathrm{~mL} 2 \% \mathrm{OsO}_{4}$ and stored at $4{ }^{\circ} \mathrm{C}$ for $1-$ $2 \mathrm{~h}$. Then, the blocks were washed three times in HEPES buffer, resuspended in $1 \%$ uranyl acetate and incubated for $1 \mathrm{~h}$ at room temperature. The blocks were dehydrated using $1 \mathrm{~mL}$ each of a graded ethanol series (25\% vol., $50 \%$ vol., $75 \%$ vol., $100 \%$ vol.) incubating for 15 min each. The blocks were then resuspended in $1 \mathrm{~mL}$ of a $50 \%$ vol. LR White resin (London Resin Company, Berkshire, UK) in anhydrous ethanol and stored at $4^{\circ} \mathrm{C}$ until the blocks sink to the bottom of the tube. After that, the blocks were resuspended in $1 \mathrm{~mL}$ 100\% LR White resin, placed into gelatin capsules containing LR White resin and incubated at $60^{\circ} \mathrm{C}$ over night to allow resin to polymerize. The capsules were shaped trimming away the exterior polymer with a razor blade, creating a trapezoid shape. $0.35 \mu \mathrm{m}$ thick thin sections were cut at a speed of $1 \mathrm{~mm} / \mathrm{s}$ using a Reichert Ultracut E microtome (Leica Microsystems, Bannockburn, IL, USA). Slices were collected on the carbon site of a copper grid.

Electron micrograph images were analyzed following the principles of stereology. A homologous sample, random slice selection and random orientation of cells on the slide were assumed. According to the Delesse principle, the area ratio of smaller elements randomly arranged in a bigger area to the big area equals the volume ratio of small elements to the bigger volume (Delesse 1848). This principle is 
applicable to microscopy and for our experiment setup it means:

$$
\frac{\sum \text { granule area }}{\sum \text { cell area }}=\frac{\sum \text { granule volume }}{\sum \text { cell volume }}
$$

The mechanistic error determining the cell and granule area was estimated by 10 fold determination of the cell and granule area of a randomly picked cell. Area ratio was determined for each of the measurements. The average of the granules per cell $(\overline{\mathrm{x}})$ was calculated, as well as the standard deviation $(\sigma)$ and the standard error $\left(\sigma_{\bar{x}}\right)$ and the standard error in percent $\left(\sigma_{\bar{x}}(\%)\right)$ according to formulas (4) through (7).

$$
\begin{aligned}
& \overline{\mathrm{x}}=\frac{\sum \mathrm{n}_{\text {granules }}}{\mathrm{n}_{\text {cells }}} \\
& \sigma=\sqrt[2]{\frac{\sum\left(\mathrm{x}_{\mathrm{i}}-\overline{\mathrm{x}}\right)^{2}}{\mathrm{n}-1}} \\
& \sigma_{\overline{\mathrm{x}}}=\frac{\sigma}{\sqrt[2]{\mathrm{n}}} \\
& \sigma_{\overline{\mathrm{x}}}(\%)=\frac{\sigma_{\overline{\mathrm{x}}}}{\overline{\mathrm{x}}} \times 100 \%
\end{aligned}
$$

For each strain the number of granules per full size cell picture $\left(\mathrm{n}_{\text {granules }}\right)$ was determined as well as the total number of full length cells ( $n_{\text {cells }}$, or $n$ in formulas 5 and 6). A cell with a length to width ratio of at least 3:1 was assumed to be a full grown cell. The arithmetic mean of granules per cell $(\overline{\mathrm{x}})$ and the standard deviation $(\sigma)$ and the standard error $\left(\sigma_{\bar{x}}\right)$ were determined for each strain using the formulas 4, 5 and 6. Assuming a Gaussian normal distribution of the granule number per cell, the average of the whole population $(\mu)$ would be $\mu=\bar{x} \pm 2 \sigma$ with a probability of $68 \%$ and $\mu=\bar{x} \pm 2 \sigma$ with a probability of $95 \%$ (Rudolf and Kuhlisch 2008). CS3 (Version 10.0, Adobe, San Jose, CA) and Paint.NET V3.5.5 (Washington State University/Microsoft, Pullman/Redmond, WA) were used to crop photographs used in this work.

\section{Results}

\section{Plasmid construction and overexpression of phaZ genes}

The plasmids pER1, pER2, pER3 and pER4 were constructed with the goal of overexpression of $R$. eutropha intracellular and putative intracellular phaZ genes in the wild type strain, $\mathrm{H} 16$, as well as complementation of PHB utilization deficiencies in the phaZ mutant strains. As discussed in Materials and Methods, the broad host-range vector pBBR1MCS-2 was used as a parental plasmid to construct the phaZ overexpression plasmids. Upstream of the multiple cloning site of $\mathrm{pBBR} 1 \mathrm{MCS}-2$ is a $\mathrm{P}_{\text {lac }}$ promoter that typically allows for expression of cloned genes in E. coli (Kovach et al. 1995). However, this promoter has been demonstrated to drive expression of genes in an $R$. eutropha host strain under growth and PHB production conditions (Fukui et al. 2011). In this study, the phaZ genes were cloned into the vector so they are expressed under the $\mathrm{P}_{\text {lac }}$ promoter. To demonstrate overexpression of phaZ1, phaZ2, phaZ3 or phaZ5 genes in strains of $R$. eutropha containing the prerequisite plasmid, mRNA levels were compared in strains with plasmid versus strains containing empty vector by RT-qPCR and consequent determination of cDNA concentration. Cells were therefore grown in rich medium cultures for approximately $8 \mathrm{~h}$, and total cellular RNA was harvested from cells for detection of phaZ genes by RT-qPCR.

A significantly higher concentration of phaZ-specific cDNA was found in $\mathrm{H} 16$ strains containing plasmids pER1-4 than in the control (empty vector alone) strain H16/pBBR1MCS-2 (Table 4). These observations suggest that phaZ gene is overexpressed in the plasmid containing strains. In H16/pBBR1MCS-2, no cDNA

\begin{tabular}{|c|c|c|}
\hline Gene $^{a}$ & Plasmid present $^{\mathrm{b}}$ & Concentration of cDNA [ng/ $\mu \mathrm{L}]^{\mathrm{c}}$ \\
\hline \multirow[t]{2}{*}{ phaZ1 } & pER1 & $4.21 \mathrm{E}-06$ \\
\hline & & $3.05 \mathrm{E}-06$ \\
\hline \multirow[t]{2}{*}{ phaZ1 } & pBBR1MCS-2 & 3.07E-07 \\
\hline & & $2.63 \mathrm{E}-07$ \\
\hline \multirow[t]{2}{*}{ phaZ2 } & pER2 & $1.22 \mathrm{E}-04$ \\
\hline & & $6.45 \mathrm{E}-05$ \\
\hline \multirow[t]{2}{*}{ phaZ2 } & pBBR1MCS-2 & $n d^{d}$ \\
\hline & & $n d^{d}$ \\
\hline \multirow[t]{2}{*}{ phaZ3 } & pER3 & $3.68 \mathrm{E}-07$ \\
\hline & & $1.01 \mathrm{E}-07$ \\
\hline \multirow[t]{2}{*}{ phaz3 } & pBBR1MCS-2 & $n d^{d}$ \\
\hline & & $n d^{d}$ \\
\hline \multirow[t]{2}{*}{ phaz5 } & pER4 & 3.07E-07 \\
\hline & & $6.35 \mathrm{E}-07$ \\
\hline \multirow[t]{2}{*}{ phaZ5 } & pBBR1MCS-2 & $2.92 \mathrm{E}-09$ \\
\hline & & $8.48 \mathrm{E}-10$ \\
\hline
\end{tabular}

Table 4 Concentration of phaZ1-phaZ5 cDNA [ng/ $\mu \mathrm{L}$ ] detected in RT-qPCR for H16/pBBR1MCS-2, H16/pER1, H16/pER2, H16/pER3, H16/pER4 amplified from $100 \mathrm{ng}$ of RNA

Indicates the primer pair of the corresponding phaZ gene used in the RT-qPCR reaction.

${ }^{b}$ Indicates the overexpression plasmid, or empty vector (pBBR1MCS-2), present in the $\mathrm{R}$. eutropha $\mathrm{H} 16$ host strain.

'Top and bottom numbers of each sample represent results of two different experiments (ex. " $4.21 \mathrm{E}-06^{\prime \prime}$ corresponds to $4.21 \times 10^{-6}$ ).

${ }^{\mathrm{d}}$ Transcript not detected by RT-qPCR. 
from mRNA of the phaZ2 or phaZ3 genes could be detected under the given conditions. This is likely because of the low levels of expression of these two genes under rich medium growth conditions (Sinskey laboratory, unpublished data). Concentration of phaZ5 cDNA from the RT-qPCR experiment was very low in H16/pBBR1MCS-2 (Table 4), likely also due to low gene expression under conditions tested. Expression of phaZ genes was also examined under $\mathrm{PHB}$ production and $\mathrm{PHB}$ consumption conditions. In both of these conditions, strains containing plasmids pER1, pER2, pER3, or pER4 demonstrated overexpression of their respective phaZ genes as compared to the control (Additional file 2: Figure S2).

\section{Examination of PHB content of $R$. eutropha strains overexpressing phaZ genes and grown under different conditions}

In rich medium (Figure 1A), the average intracellular PHB content reached its highest level (between $8 \%$ and $18 \%$ of cdw) after $4 \mathrm{~h}$ of cultivation for all strains. After this climax, the PHB content declined slightly over the next $5 \mathrm{~h}$. After $24 \mathrm{~h}$, the intracellular PHB content had decreased to $2 \%-6 \% \mathrm{cdw}$. After $48 \mathrm{~h}$, the PHB was completely depleted. No significant differences could be detected between the different plasmid-bearing strains and the control. This transient PHB accumulation in rich media cultures was similar to observations from previous works (Tian et al. 2005a; York et al. 2003).

In growth medium formulated to promote PHB production (Figure 1B), no significant PHB production could be observed during the first $10 \mathrm{~h}$, likely corresponding to cell growth and the presence of extracellular nitrogen. After this, the PHB content steadily increased to a concentration of $70 \%-80 \% \mathrm{cdw}$ after 48 hours. The final PHB content (after $72 \mathrm{~h}$ ) for all strains was $\sim 80-90 \% \mathrm{cdw}$. No significant differences could be detected between the different plasmid bearing strains and the control, indicating that overexpression of phaZ genes has no effect on intracellular PHB accumulation in R. eutropha.

In $\mathrm{PHB}$ consumption medium (Figure $1 \mathrm{C}$ ), minimal medium with no exogenous carbon, the intracellular PHB accumulated during the PHB production phase was used as a carbon source. A rapid decrease in PHB content from $90 \% \mathrm{cdw}$ to $\sim 60 \% \mathrm{cdw}$ could be observed during the first $10 \mathrm{~h}$. From $10 \mathrm{~h}$ to $72 \mathrm{~h}$, the PHB content decreased more moderately from $60 \%$ to $40 \%-50 \%$ cdw. After $24 \mathrm{~h}$, the PHB content in the strains H16/pER1 and H16/pER2 had already decreased to $40 \% \mathrm{cdw}$, whereas $\sim 60 \% \mathrm{cdw}$ intracellular PHB still remained in the other strains. This observation suggests that the overexpression of phaZ1 and phaZ2 resulted in an increased rate of intracellular PHB utilization over the first $24 \mathrm{~h}$. After $24 \mathrm{~h}$, no significant differences could be detected between the different plasmid-bearing strains and the control.

\section{Complementation of $R$. eutropha strain Re2005}

We also examined PHB content in Re2005 ( $\Delta$ phaZ1 1 -

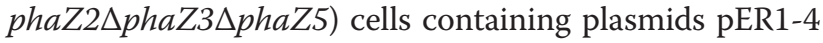
under PHB utilization conditions (Figure 2), attempting to complement the $\mathrm{PHB}$ utilization phenotype of the strain. Intracellular $\mathrm{PHB}$ accumulated under polymer production conditions remained approximately the same ( 80\% cdw) in Re2005/pER3, Re2005/pER4 and Re2005/ pBBR1MCS2. This suggests that addition of phaZ3 or phaZ5 genes to a Re2005 host in trans does not result in complementation of the PHB utilization phenotype. In PHB utilization conditions, for Re2005/pER1 the intracellular PHB content did not decrease for the first $10 \mathrm{~h}$, and then exhibited a linear decrease from $\sim 80 \%$ of $\mathrm{cdw}$ to $\sim 50 \%$ of $\mathrm{cdw}$ over the next $62 \mathrm{~h}$. This observation suggests that phaZ1 will complement the phenotype of Re2005 when introduced in trans. In Re2005/pER2 a steep decline from $\sim 80 \% \mathrm{cdw}$ to $\sim 55 \% \mathrm{cdw}$ was observed during the first $8 \mathrm{~h}$. From $10 \mathrm{~h}$ to $24 \mathrm{~h}$, the PHB content decreased more moderately from $\sim 55 \% \mathrm{cdw}$ to $\sim 45 \%$ cdw. After that, it remains stable at $\sim 45 \% \mathrm{cdw}$. The final concentration for Re2005/pER2 is reached after $\sim 24 \mathrm{~h}$, whereas Re2005/pER1 commences PHB consumption between $10 \mathrm{~h}-24 \mathrm{~h}$, so Re2005/pER2 seems to have reached almost the final PHB level when Re2005/pER1 has just begun PHB consumption. These observations could imply that PhaZ2, expressed from pER2, is more efficient in mobilizing PHB from granules than is PhaZ1, expressed from pER1. In summary, these observations suggest that the overexpression of either phaZ1 or phaZ2 in this strain restore the ability of $\operatorname{Re} 2005$ to utilize PHB under the given conditions, whereas the overexpression of phaZ3 and phaZ5 appears to have no effect.

\section{Electron Microscopy}

Electron microscopy was performed to determine the effect of phaZ deletions on granule count, size, and shape in $R$. eutropha. It is already an established method to visualize $R$. eutropha H16 cells and granules under different growth and PHB production conditions (Tian et al. 2005a, 2005b). The amount (Tables 5 and 6) and quality (examples in Figure 3) of $R$. eutropha cell and granule images in the obtained micrographs were suitable for statistical analysis.

In Table 5, the area ratios of electron micrograph images of each strain are listed. The Delesse principle tells us that the area ratio of smaller elements (in this case, 2-dimentional representations of granules) randomly arranged in a larger space (in this case, the 2-dimensional representation of the cell) compared to the area of that larger space equals 


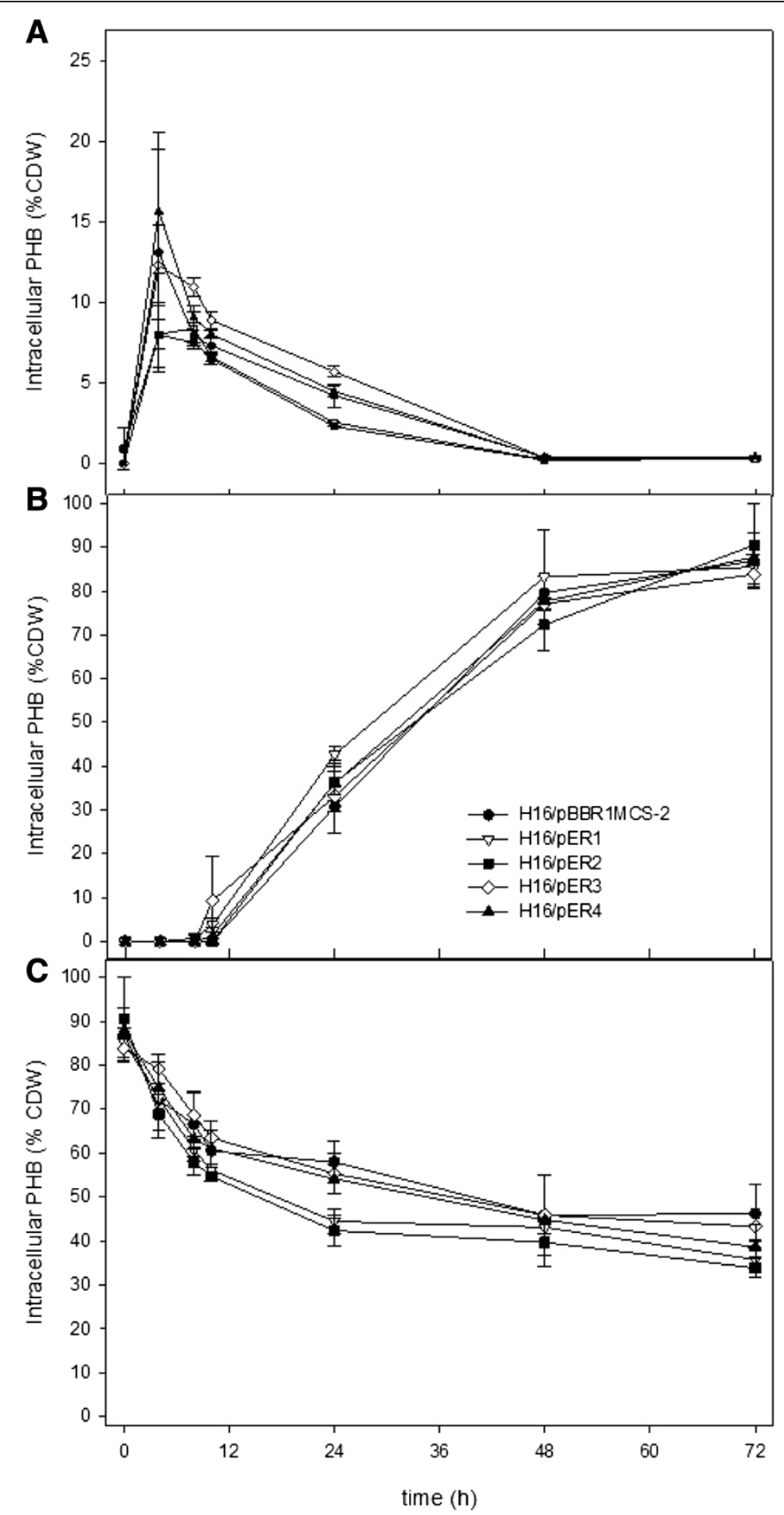

Figure 1 PHB content as percentage of cell dry weight (CDW) in R. eutropha cultures grown in (A) TSB (rich) medium, (B) PHB production medium (minimal medium with $0.05 \mathrm{w} / \mathrm{v} \% \mathrm{NH}_{4} \mathrm{Cl}$ and $2 \mathrm{w} / \mathrm{v} \%$ fructose), and (C) PHB consumption medium (minimal medium with $0.1 \mathrm{w} / \mathrm{v} \% \mathrm{NH}_{4} \mathrm{Cl}$ and no exogenous carbon source). PHB content for the strains H16/pBBR1MCS-2 (vector alone control), H16/ pER1 (overexpressing phaZ1), H16/pER2 (overexpressing phaZ2), H16/pER3 (overexpressing phaZ3), H16/pER4 (overexpressing phaZ5) are shown here. Values represented in these graphs are the averages of duplicate experiments. Error bars indicate standard deviation. 


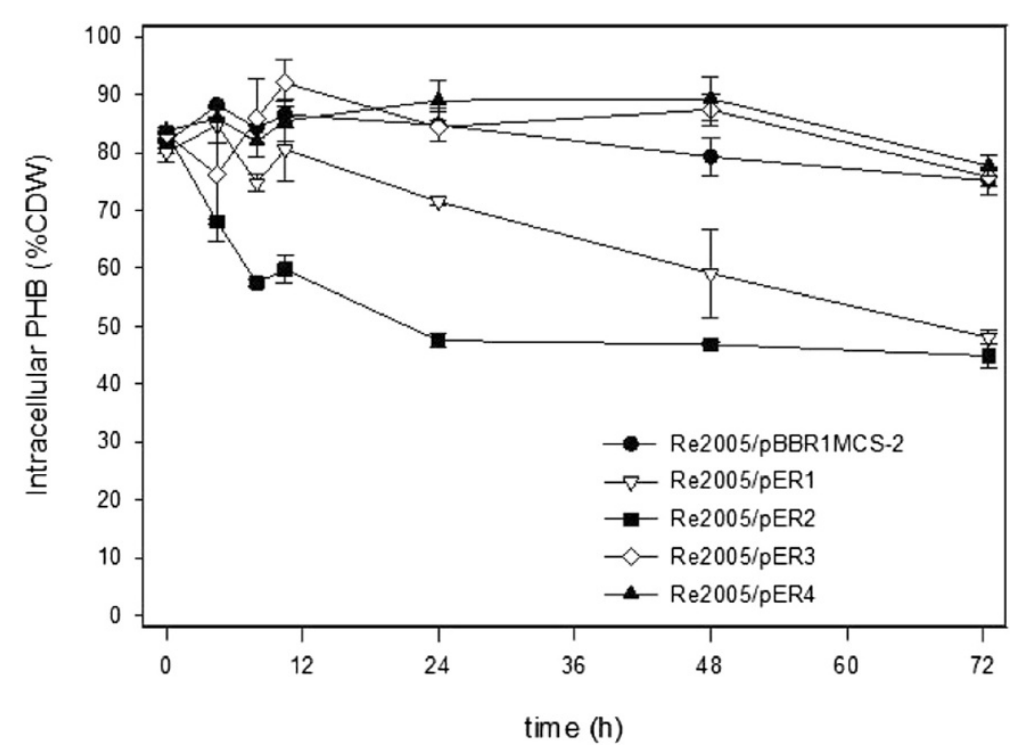

Figure 2 PHB content of Re2005 (LphaZ1 in PHB consumption medium (minimal medium with $0.1 \mathrm{w} / \mathrm{v} \% \mathrm{NH}_{4} \mathrm{Cl}$ and no exogenous carbon source). PHB contents for the strains Re2005/pBBR1MCS-2, Re2005/pER1 (+phaZ1), Re2005/pER2 (+phaZ2), Re2005/pER3 (+phaZ3), Re2005/pER4 (+phaZ5) over the course of a $72 \mathrm{~h}$ incubation time are shown here. Values represented in this graph are the average of triplicate experiments. Error bars indicate the standard deviation.

the volume ratio of the small elements (granules) to the bigger area (cell). In short, we can estimate the amount of space inside the cell of each strain taken up by PHB granules, and estimate if the deletion of phaZ genes plays a role in altering that ratio. The mechanistic standard error, in percent $\left(\sigma_{\overline{\mathrm{x}}}(\%)\right)$, for the determination of granule/cell area ratio was found to be $2.01 \%$ (Table 5 ). The data shown in Table 5 indicate that strains Re1110 ( $\Delta p h a Z 2)$ and Re1112 ( $\triangle p h a Z 1 \Delta p h a Z 2)$ exhibit a slight increase in the granule/ cell area ratio. This suggests that the loss of PhaZ2 has a slight effect on the granule/cell area ratio, indicating a potential function of PhaZ2 in shaping and remodeling PHB

Table 5 Area ratios, standard error in percent $\left(\sigma_{\overline{\mathbf{x}}}(\%)\right)$ and sample sizes ( $n$ ) of the area ratios for $\mathrm{H} 16, \mathrm{Re} 1097$

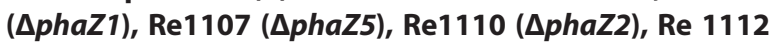

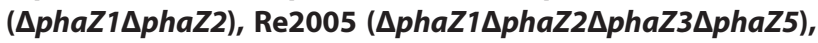
Re2006 (DphaZ3)

\begin{tabular}{lrrr}
\hline & Area ratio & $\begin{array}{r}\text { standard error } \\
\text { in percent, }\left(\boldsymbol{\sigma}_{\overline{\mathbf{x}}},(\%)\right)\end{array}$ & Sample size $(\mathbf{n})$ \\
\hline H16 & 0.25 & 2.01 & 97 \\
Re1097 & 0.28 & 2.01 & 106 \\
Re1107 & 0.29 & 2.01 & 98 \\
Re1110 & 0.30 & 2.01 & 101 \\
Re1112 & 0.32 & 2.01 & 100 \\
Re2005 & 0.22 & 2.01 & 99 \\
Re2006 & 0.27 & 2.01 & 101 \\
\hline
\end{tabular}

granules in the $R$. eutropha cell. The quadruple deletion

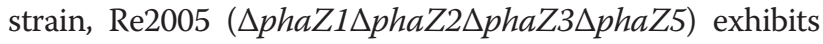
a slight decrease in the area ratio, suggesting other PhaZ enzymes may also have granule shaping and remodeling functions.

While it has been shown that the presence or absence of PHB depolymerase enzymes does not control the overall amount of PHB in the cell, a role of these enzymes in granule formation is strongly suggested, both by the presence of PhaZ proteins on the surface of PHB granules (Uchino and Saito 2006; Uchino et al. 2007) and the alteration of granule/cell area ratios in phaZ

Table 6 Average granule count per cell $(\bar{x})$, standard error $\left(\sigma_{\bar{x}}\right)$ and sample size $(n)$ of the area ratios for $\mathrm{H16}$,

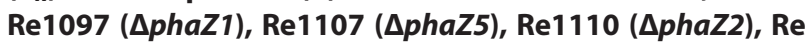

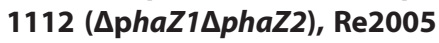

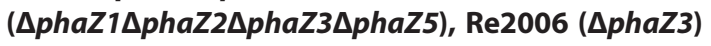

\begin{tabular}{llll}
\hline $\begin{array}{l}\text { R. eutropha } \\
\text { strain }\end{array}$ & $\begin{array}{l}\text { Average }(\overline{\mathbf{x}}) \\
\text { granules/cell }\end{array}$ & $\begin{array}{l}\text { Standard error } \\
\left(\boldsymbol{\sigma}_{\bar{x}}\right)\end{array}$ & $\begin{array}{l}\text { Sample size } \\
(\mathbf{n})\end{array}$ \\
\hline H16 & 5.56 & 0.54 & 18 \\
Re1097 & 5.41 & 0.63 & 18 \\
Re1107 & 5.55 & 0.47 & 20 \\
Re1110 & 6.83 & 0.40 & 24 \\
Re1112 & 7.06 & 0.45 & 17 \\
Re2005 & 5.39 & 0.37 & 18 \\
Re2006 & 7.00 & 0.46 & 16 \\
\hline
\end{tabular}




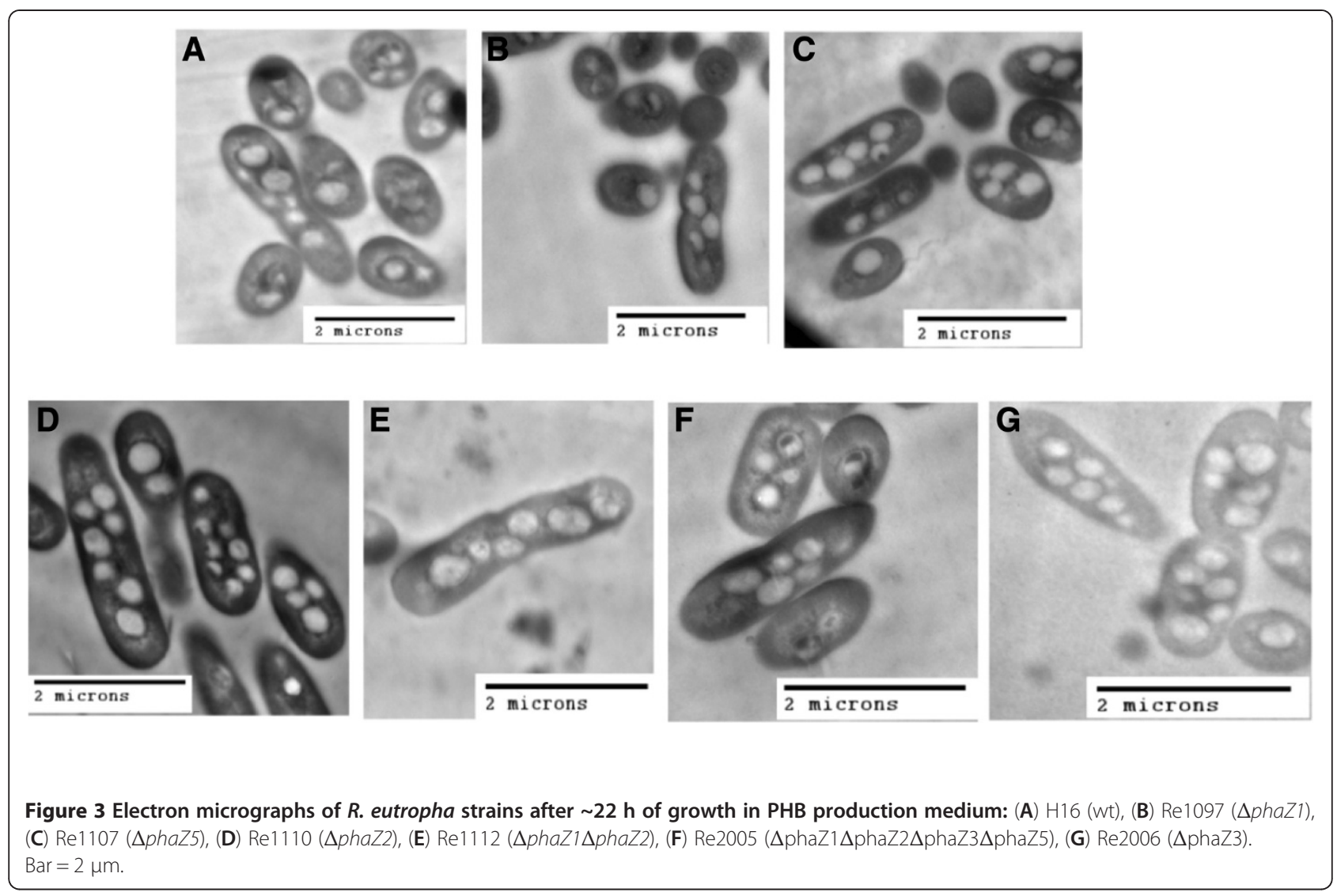

mutant strains. We sought to determine whether PHB depolymerase genes played a role in the number of granules present inside the cell. Table 6 shows the average granule count of $R$. eutropha wild type and phaZ mutant strains. Individual standard errors for the average granule count ranged between $\sim 6 \%$ and $\sim 12 \%$. Quantitative data could be derived from the statistical analysis: In Re1110

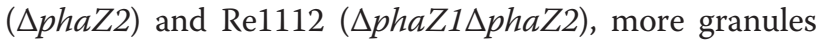
were observed per cell than in the wild type strain, H16. These observations suggest that PhaZ enzymes play roles in granule formation, potentially via control of the number of granules per cell. Strain Re2006 (DphaZ3) showed a high granule number per cell, whereas the ratio of granule to cell area was only slightly higher than in the wild type. This suggests that the presence of PhaZ3 in the $R$. eutropha cell may affect granule formation through control of intracellular granule count. Granule count in Re1097 and Re1107 did not significantly differ from the wild type, whereas the cell/granule area ratio was slightly higher. In general, these observations suggest that the absence of specific phaZ genes affects granule number and architecture in different strains.

\section{Discussion}

Data shown here indicate that overexpression of phaZ1 and phaZ2 genes has an effect on PHB consumption in
R. eutropha strains H16 and Re2005 (Figures 1C and 2). The active role of these enzymes in PHB consumption was shown earlier by analysis of PHB content in phaZ1 and phaZ2 deletion strains (York et al. 2003). In $R$. eutropha H16, overexpression of these genes seems to have a minor effect on PHB homeostasis. Utilization of PHB appears to be accelerated in H16/pER1 and H16/ pER2 (Figure 1C), but the overexpression of phaZ1 and phaZ2 does not seem to have a significant effect on the final PHB content after $72 \mathrm{~h}$ in PHB utilization medium. In Re2005/pER2, PHB levels similar to those of the wild type strain are almost reached when the strain is incubated in PHB consumption medium. Furthermore, the final PHB content is almost reached in Re2005/pER2 (i.e. the cells have mobilized near maximum amount of PHB under utilization conditions) when Re2005/pER1 begins polymer consumption. This observation suggests that phaZ2 expression can complement the phenotype of the quadruple depolymerase mutant, in terms of overall PHB mobilization. This might also indicate that PhaZ1 acts upon products of PhaZ2 under conditions examined in this work. The opposite - PhaZ2 acting upon products of PhaZ1 activity - had been suggested in an earlier work, based upon analysis of gene deletion mutants (York et al. 2003). Furthermore, in Re2005, expression of phaZ1 in trans resulted in linear kinetics of $\mathrm{PHB}$ 
consumption over time, whereas expression in trans of phaZ2 seemed to bring about exponential kinetics of utilization. This suggests different kinetics of PHB depolymerase activity of these two enzymes. It is possible that the manner of cooperation between PhaZ1 and PhaZ2 enzymes is dependent on the depolymerase enzyme associated with the PHB granule.

According to York, et al. (York et al. 2003), a single deletion of the phaZ2 gene does not have an effect on the total amount of PHB mobilized in $R$. eutropha cultures. This observation, along with data shown here, suggests that PhaZ2 enables PHB consumption but that it is not necessarily required in presence of PhaZ1. Microarray data (Brigham et al. 2012) suggest that expression of phaZ1 is slightly upregulated during $\mathrm{PHB}$ production in comparison to growth and slightly down regulated during consumption in comparison to PHB production. Expression of phaZ2 appears to be high under PHB production conditions. It remains unclear why individual overexpression of phaZ1 and especially phaZ2 in $R$. eutropha H16 does not appear to result in a more pronounced effect on intracellular PHB content under polymer production conditions. One possible explanation is that action of PhaZ2 causes a rearrangement of PHB polymer chains and then contributes degradation in an early stage of PHB consumption. Observed differences in granule/cell area ratios (Table 5) and granule counts (Table 6) in strains Re1110 (DphaZ2) and Re1112 ( $\Delta$ phaZ1 1 phaZ2), when compared to wild type, suggest that PhaZ2 could indeed have a granule formation/remodeling role in the $R$. eutropha cell.

From the calculated area ratios, we can conclude that

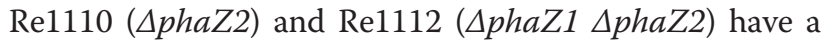
higher granule volume per cell volume compared to the wild type. This increased volume ratio can be attributed to higher granule counts (per cell) in these strains in comparison to wild type. Analysis of the PHB content in these strains (York et al. 2003) has shown that Re1110 and Re1112 contain the same amounts of PHB as the wild type strain, after $24 \mathrm{~h}$ growth in $\mathrm{PHB}$ production medium. Accordingly, the same amount of PHB would be distributed over a larger number of granules. Preliminary fluorescence microscopy data suggests that strain H16/pER2 (with expression of phaZ2 in trans) displayed a lower granule count than the wild type and the other overexpressing strains (data not shown). Table 6 shows that a deletion of phaZ2 results in a slight increase of granule number per cell. These two observations suggest an effect of PhaZ2 on the 3-dimensional architecture of the granules or, more specifically, on their density.

While it is clear from our data and previously published data (York et al. 2003) that PhaZ1 and PhaZ2 play major roles in PHB homeostasis in $R$. eutropha, data from the present work suggest roles for the two previously uncharacterized (or little characterized) depolymerases, PhaZ3 and PhaZ5. Neither PhaZ3 nor PhaZ5 were shown to play a noticeable role in PHB mobilization, suggesting their roles in PHB homeostasis are more subtle. According to the calculated area ratios, a slight but significant decrease in granule volume per cell volume is estimated in Re2005 ( $4 p h a Z 1 \Delta p h a Z 2 \Delta p h a Z 3 \Delta p h a Z 5)$ compared to wild type (Table 5). Moreover, a low granule count was observed in this strain in comparison to wild type (Table 6). Re2006 ( $\triangle p h a Z 3)$ displayed a high granule count, but the granule volume per cell volume was estimated to be slightly but significantly higher than that of the wild type. Analysis of the PHB content in these strains (data not shown) suggests that Re2005 and Re2006 have the same PHB content as wild type under the conditions tested. This indicates higher granule density in Re2005 and Re2006. It also supports the hypothesis that PhaZ enzymes, specifically the newly characterized PhaZ3, are involved in 3D architecture of granules. Re1107 ( $\triangle$ phaZ5) exhibited a higher area ratio than wild type, suggesting increased granule volume per cell volume, even though granule count was similar between the two strains. According to previous results (York et al. 2003), the intracellular PHB contents between the two strains are similar. This suggests that Re1107 has a lower granule density than wild type, suggesting a role for PhaZ5 in PHB granule architecture remodeling. Thus, while PhaZ3 and PhaZ5 enzymes do not appear to participate in PHB mobilization in a significant way, they do appear to affect the granule architecture inside the cell. It is also possible that crystallinity of intracellular PHB may be altered in these mutant strains.

Over the past three decades of research, many factors have been linked with PHB granule formation in R. eutropha. Initially, the PHB synthase enzyme was demonstrated to be associated with granules (Gerngross et al. 1993), and obviously plays a major role in formation of the intracellular bodies. Phasin proteins were also found to be associated with granules, with their primary and secondary structures making them well-suited for separating the hydrophobic polymer from the hydrophilic cytoplasmic contents (Pötter et al. 2002; York et al. 2001). PhaR protein, also thought to be granule-associated (Yamada et al. 2007; Yamashita et al. 2006), regulates the expression of the most abundant phasin protein, PhaP1, and has been shown to be able to bind DNA at a specific locus (York et al. 2002), as well as non-specifically on hydrophobic PHB (Yamada et al. 2007). Recently, a new type of protein factor, PhaM was discovered in $R$. eutropha (Pfeiffer et al. 2011). The role of PhaM was localization of granule initiation and provided a link between granule formation and the nucleoid of the cell, suggesting that PHB granules form not at the site of the cytoplasmic membrane, but in the cytoplasm itself (Pfeiffer et al. 2011). It was also shown that the intracellular depolymerase PhaZ1 was associated with 
granules, and functioned in thiolysis of 3HB-CoA from PHB chains in the granules (Uchino and Saito 2006; Uchino et al. 2007). PhaZ2 was also shown to play a role in PHB degradation (York et al. 2003), suggesting its presence on the surface of the PHB granule. From our studies discussed here, it is tempting to speculate a PHA granuleassociated role for the other known intracellular PHB depolymerases, PhaZ3 and PhaZ5, perhaps assisting with remodeling of the polymer chains within the granule. Given the complexity of the protein machinery surrounding the PHB granule, allowing for polymer to be synthesized or broken down as extracellular nutrient availability dictates, it can be said that the polymer granules truly are bacterial intracellular organelles (Jendrossek 2009).

Uncovering the biology of PHB homeostasis in the model organism, $R$. eutropha, is advantageous for future studies on applications of the polymer. It will allow for development of bioprocesses with recovery of a maximum amount of useful biodegradable polymer from cells with minimal effort, allowing for easier polymer characterization and biocompatibility studies. Given the attractiveness of PHA in medical and tissue engineering applications, a thorough understanding of $R$. eutropha PHA biosynthesis could lead to a new role for the bacterium as an attractive industrial organism.

\section{Additional files}

Additional file 1: Figure S1. Confirmation of deletion of the phaZ3 gene from the R. eutropha chromosome.

Additional file 2: Figure S2. Quantitative ratios of phaZ transcript amounts in H16 strains containing pBBR1MCS-2 (vector only), pER1 (with phaZ1 gene), pER2 (with phaZ2 gene), pER3 (with phaZ3 gene), or pER4 (with phaZ5 gene).

\section{Competing interests}

The authors declare that they have no competing interests.

\section{Acknowledgements}

We thank Dr. Daniel MacEachran and Dr. Kelly Knee for valuable assistance with electron microscopy studies. We thank Mr. John W. Quimby for critical review of this manuscript and valuable assistance with stereology and other EM image studies. We thank Mr. Aidan Smith for help with RT-PCR experiments shown in this work. We also thank Ms. Tatiana Berger for help with growth experiments. CJB is supported by Advanced Research Projects Agency - Energy (ARPA-E). This work was supported by a grant from the government of Malaysia and the Malaysian Office of Science, Technology, and Innovation (MOSTI). The result of this grant, the Malaysia MIT Biotechnology Partnership Program (MMBPP), is a collaboration between MIT, SIRIM Berhad, Universiti Sains Malaysia, and Universiti Putra Malaysia. The authors would like to thank the other members of this program for their support and collegial collaborations.

\section{Author details}

'Department of Biology, Massachusetts Institute of Technology, Cambridge, MA 02139, USA. ²WTH Aachen University, 52062 Aachen, Germany.

${ }^{3}$ Biomaterials Science and Engineering Laboratory, Massachusetts Institute of Technology, Cambridge, MA 02139, USA. ${ }^{4}$ Division of Health Sciences Technology, Massachusetts Institute of Technology, Cambridge, MA 02139,
USA. ${ }^{5}$ Engineering Systems Division, Massachusetts Institute of Technology, Cambridge, MA 02139, USA.

Received: 12 January 2012 Accepted: 26 April 2012

Published: 26 April 2012

\section{References}

Abe T, Kobayashi T, Saito T (2005) Properties of a novel intracellular poly (3-hydroxybutyrate) depolymerase with high specific activity (PhaZd) in Wautersia eutropha H16. J Bacteriol 187:6982-6990

Anderson AJ, Dawes EA (1990) Occurrence, metabolism, metabolic role, and industrial uses of bacterial polyhydroxyalkanoates. Microbiol Rev 54:450472

Brigham CJ, Budde CF, Holder JW, Zeng Q, Mahan AE, Rha C, Sinskey AJ (2010) Elucidation of beta-oxidation pathways in Ralstonia eutropha $\mathrm{H} 16$ by examination of global gene expression. J Bacteriol 192:5454-5464

Brigham CJ, Speth DR, Rha C, Sinskey AJ (2012) Whole genome microarray analysis reveals guanosine tetraphosphate governing the polyhydroxyalkanoate production cycle in Ralstonia eutropha H16. 2010, Manuscript in preparation

Budde CF, Mahan AE, Lu J, Rha C, Sinskey AJ (2010) Roles of multiple acetoacetyl coenzyme $\mathrm{A}$ reductases in polyhydroxybutyrate biosynthesis in Ralstonia eutropha H16. J Bacteriol 192:5319-5328

Budde CF, Riedel SL, Willis LB, Rha C, Sinskey AJ (2011) Production of Poly (3-Hydroxybutyrate-co-3-Hydroxyhexanoate) from Plant Oil by Engineered Ralstonia eutropha Strains. Appl Environ Microbiol 77:2847-2854

Chee J-W, Amirul AA, Muhammad TST, Majid MIA, Mansor SM (2008) The influence of copolymer ratio and drug loading level on the biocompatibility of $\mathrm{P}(3 \mathrm{HB}-\mathrm{CO}-4 \mathrm{HB})$ synthesized by Cupriavidus sp. (USMAA2-4). Biochem Eng J 38:314-318

Chen GQ, Wu Q (2005) The application of polyhydroxyalkanoates as tissue engineering materials. Biomaterials 26:6565-6578

Cheng ST, Chen ZF, Chen GQ (2008) The expression of cross-linked elastin by rabbit blood vessel smooth muscle cells cultured in polyhydroxyalkanoate scaffolds. Biomaterials 29:4187-4194

Delesse A (1848) Procede mecanique pour determiner la composition des roches. Ann Mines 379:13

Fukui T, Ohsawa K, Mifune J, Orita I, Nakamura S (2011) Evaluation of promoters for gene expression in polyhydroxyalkanoate-producing Cupriavidus necator H16. Appl Microbiol Biotechnol 89:1527-1536

Gerngross TU, Reilly P, Stubbe J, Sinskey AJ, Peoples OP (1993) Immunocytochemical analysis of poly-beta-hydroxybutyrate (PHB) synthase in Alcaligenes eutrophus $\mathrm{H16}$ : localization of the synthase enzyme at the surface of PHB granules. J Bacteriol 175:5289-5293

Handrick R, Reinhardt S, Jendrossek D (2000) Mobilization of poly (3-hydroxybutyrate) in Ralstonia eutropha. J Bacteriol 182:5916-5918

Ishizaki A, Tanaka K, Taga N (2001) Microbial production of poly-D-3-hydroxybutyrate from $\mathrm{CO}_{2}$. Appl Microbiol Biotechnol 57:6-12

Jendrossek D (2009) Polyhydroxyalkanoate granules are complex subcellular organelles (carbonosomes). J Bacteriol 191:3195-3202

Karr DB, Waters JK, Emerich DW (1983) Analysis of Poly-beta-Hydroxybutyrate in Rhizobium japonicum Bacteroids by lon-Exclusion High-Pressure Liquid Chromatography and UV Detection. Appl Environ Microbiol 46:1339-1344

Knoll M, Hamm TM, Wagner F, Martinez V, Pleiss J (2009) The PHA Depolymerase Engineering Database: A systematic analysis tool for the diverse family of polyhydroxyalkanoate (PHA) depolymerases. BMC Bioinformatics 10:89

Kovach ME, Elzer PH, Hill DS, Robertson GT, Farris MA, Roop RM 2nd, Peterson KM (1995) Four new derivatives of the broad-host-range cloning vector pBBR1MCS, carrying different antibiotic-resistance cassettes. Gene 166:175-176

Pfeiffer D, Wahl A, Jendrossek D (2011) Identification of a multifunctional protein, PhaM, that determines number, surface to volume ratio, subcellular localization and distribution to daughter cells of poly(3-hydroxybutyrate), PHB, granules in Ralstonia eutropha H16. Mol Microbiol 82:936-951

Pötter M, Madkour MH, Mayer F, Steinbüchel A (2002) Regulation of phasin expression and polyhydroxyalkanoate (PHA) granule formation in Ralstonia eutropha H16. Microbiology 148:2413-2426

Quandt J, Hynes MF (1993) Versatile suicide vectors which allow direct selection of gene replacement in Gram-negative bacteria. Gene 127:15-21

Rehm BH (2003) Polyester synthases: natural catalysts for plastics. Biochem J 376:15-33 
Reinecke F, Steinbüchel A (2009) Ralstonia eutropha strain H16 as a model organism for PHA metabolism and for biotechnological production of technically interesting polymers. J Mol Microbiol Biotechnol 16:91-108

Reusch RN (1989) Poly-beta-hydroxybutyrate/calcium polyphosphate complexes in eukaryotic membranes. Proc Soc Exp Biol Med 191:377-381

Rudolf M, Kuhlisch W (2008) Biostatistik: Eine Einfuehrung fuer Biowissenschaftler. Pearson Studium, Munich

Sevastianov VI, Perova NV, Shishatskaya El, Kalacheva GS, Volova TG (2003) Production of purified polyhydroxyalkanoates (PHAs) for applications in contact with blood. J Biomater Sci Polym Ed 14:1029-1042

Shishatskaya El, Voinova ON, Goreva AV, Mogilnaya OA, Volova TG (2008) Biocompatibility of polyhydroxybutyrate microspheres: in vitro and in vivo evaluation. J Mater Sci Mater Med 19:2493-2502

Shishatskaya El, Volova TG, Efremov SN, Puzyr' AP, Mogil'naya OA (2002a) Tissue response to biodegradable suture threads made of polyhydroxyalkanoates. Biomed Eng 36:210-217

Shishatskaya El, Volova TG, Gitelson II (2002b) In vivo toxicological evaluation of polyhydroxyalkanoates. Dokl Biol Sci 383:109-111

Shishatskaya El, Volova TG, Gordeev SA, Puzyr AP (2005) Degradation of P(3HB) and $\mathrm{P}(3 \mathrm{HB}-\mathrm{CO}-3 \mathrm{HV})$ in biological media. J Biomater Sci Polym Ed 16:643-657

Shishatskaya El, Volova TG, Puzyr AP, Mogilnaya OA, Efremov SN (2004) Tissue response to the implantation of biodegradable polyhydroxyalkanoate sutures. J Mater Sci Mater Med 15:719-728

Shum-Tim D, Stock U, Hrkach J, Shinoka T, Lien J, Moses MA, Stamp A, Taylor G, Moran AM, Landis W, Langer R, Vacanti JP, Mayer JE Jr (1999) Tissue engineering of autologous aorta using a new biodegradable polymer. Ann Thorac Surg 68:2298-2304, discussion 2305

Simon S, Priefer T, Puehler A (1983) A broad host range mobilization system for in vivo genetic engineering: transposon mutagenesis in Gram negative bacteria. Bio/Technology 1:784-791

Sodian R, Sperling JS, Martin DP, Stock U, Mayer JE Jr, Vacanti JP (1999) Tissue engineering of a trileaflet heart valve-early in vitro experiences with a combined polymer. Tissue Eng 5:489-494

Stubbe J, Tian J, He A, Sinskey AJ, Lawrence AG, Liu P (2005) Nontemplatedependent polymerization processes: polyhydroxyalkanoate synthases as a paradigm. Annu Rev Biochem 74:433-480

Sudesh K, Abe H, Doi Y (2000) Synthesis, structure, and properties of polyhydroxyalkanoates: biological polyesters. Prog Polym Sci 25:1503-1555

Tian J, He A, Lawrence AG, Liu P, Watson N, Sinskey AJ, Stubbe J (2005a) Analysis of transient polyhydroxybutyrate production in Wautersia eutropha $\mathrm{H} 16$ by quantitative Western analysis and transmission electron microscopy. J Bacteriol 187:3825-3832

Tian J, Sinskey AJ, Stubbe J (2005b) Kinetic studies of polyhydroxybutyrate granule formation in Wautersia eutropha $\mathrm{H} 16$ by transmission electron microscopy. J Bacteriol 187:3814-3824

Uchino K, Saito T (2006) Thiolysis of poly(3-hydroxybutyrate) with polyhydroxyalkanoate synthase from Ralstonia eutropha. J Biochem 139:615-621

Uchino K, Saito T, Gebauer B, Jendrossek D (2007) Isolated poly (3-hydroxybutyrate) (PHB) granules are complex bacterial organelles catalyzing formation of PHB from acetyl coenzyme $A(C O A)$ and degradation of PHB to acetyl-CoA. J Bacteriol 189:8250-8256

Volova TG, Shishatskaya El, Sevastinov VI, Perova N (2003) Results of biomedical investigations of PHB and PHB/PHV fibers. Biochem Eng J 16:125-133

Volova TG, Voinov NA (2003) Kinetic parameters of a culture of the hydrogen-oxidizing Ralstonia eutropha, grown under the regimen of biosynthesis of polyhydroxybutyrate. Prikl Biokhim Mikrobiol 39:189-193

Yamada M, Yamashita K, Wakuda A, Ichimura K, Maehara A, Maeda M, Taguchi S (2007) Autoregulator protein PhaR for biosynthesis of polyhydroxybutyrate [P $(3 \mathrm{HB})$ ] possibly has two separate domains that bind to the target DNA and $P$ (3HB): Functional mapping of amino acid residues responsible for DNA binding. J Bacteriol 189:1118-1127

Yamashita K, Yamada M, Numata K, Taguchi S (2006) Nonspecific hydrophobic interactions of a repressor protein, PhaR, with poly[(R)-3-hydroxybutyrate] film studied with a quartz crystal microbalance. Biomacromolecules 7:2449-2454

Yang YH, Brigham CJ, Budde CF, Boccazzi P, Willis LB, Hassan MA, Yusof ZA, Rha C, Sinskey AJ (2010) Optimization of growth media components for polyhydroxyalkanoate (PHA) production from organic acids by Ralstonia eutropha. Appl Microbiol Biotechnol 87:2037-2045

York GM, Junker BH, Stubbe JA, Sinskey AJ (2001) Accumulation of the PhaP phasin of Ralstonia eutropha is dependent on production of polyhydroxybutyrate in cells. J Bacteriol 183:4217-4226
York GM, Lupberger J, Tian J, Lawrence AG, Stubbe J, Sinskey AJ (2003) Ralstonia eutropha $\mathrm{H} 16$ encodes two and possibly three intracellular Poly [D-(-)-3-hydroxybutyrate] depolymerase genes. J Bacteriol 185:3788-3794 York GM, Stubbe J, Sinskey AJ (2002) The Ralstonia eutropha PhaR protein couples synthesis of the PhaP phasin to the presence of polyhydroxybutyrate in cells and promotes polyhydroxybutyrate production. J Bacteriol 184:59-66

doi:10.1186/2191-0855-2-26

Cite this article as: Brigham et al: Examination of PHB Depolymerases in Ralstonia eutropha: Further Elucidation of the Roles of Enzymes in PHB Homeostasis. AMB Express 2012 2:26.

\section{Submit your manuscript to a SpringerOpen ${ }^{\circ}$ journal and benefit from:}

- Convenient online submission

- Rigorous peer review

- Immediate publication on acceptance

- Open access: articles freely available online

- High visibility within the field

- Retaining the copyright to your article

Submit your next manuscript at $>$ springeropen.com 